\title{
Distribution and ecology of the mayflies (Ephemeroptera) of Flanders (Belgium)
}

\author{
Koen Lock* and Peter L.M. Goethals \\ Laboratory of Environmental Toxicology and Aquatic Ecology, Ghent University, J. Plateaustraat 22, 9000 Gent, Belgium
}

Received 20 September 2010; Accepted 7 March 2011

\begin{abstract}
A literature survey and the identification of all available collection material resulted in a checklist and distribution maps for the mayflies occurring in Flanders. In addition, the relationship between the occurrence of mayflies and water characteristics was analysed. Of the 32 species that have been recorded, six are now extinct in Flanders (three of which are potamal species), while the majority of the remaining species are rare and their populations are often strongly isolated and therefore extremely vulnerable. Waters with relatively low oxygen levels and high conductivities were characterized by the most tolerant mayfly species Cloeon dipterum and Caenis robusta. However, most other species only occurred at higher oxygen concentrations and lower conductivities and could be separated into two groups. The first group mainly occurred in waters with a high $\mathrm{pH}$ and were often restricted to the loamy region or to stagnant waters, while the second group occurred in waters with a lower $\mathrm{pH}$ and mainly occurred in the Campine region. For most mayfly species, sustainable populations can only be achieved when their current habitats are adequately protected and, in addition, measures should be taken to connect and enlarge the remaining populations.
\end{abstract}

Key words: Checklist / distribution maps / ecoregions

\section{Introduction}

River management in Flanders has been conducted at the river basin level using wastewater treatment plants and imposed standards of effluent concentrations. Although these measures resulted in a significant improvement of the chemical and ecological water quality since the 1980s (VMM, 2010), many Flemish water bodies still lack the good ecological status that the European Union Water Framework Directive (WFD) requires by 2015 (European Council, 2000). The use of biotic indicators, such as macrobenthic fauna, fish fauna, phytoplankton, phytobenthos and macrophytes, is required by the WFD to assess the ecological water quality.

In the past, the Flemish Environment Agency used the Belgian Biotic Index (BBI; De Pauw and Vanhooren, 1983), which has been adopted as a standard method for assessing river water quality by means of macroinvertebrates by the Belgian Institute of Normalization (IBN, 1984). Recently, however, the Multimetric Macroinvertebrate Index Flanders (MMIF; Gabriels et al., 2010) was developed in order to meet the requirements of the WFD. In both indexes, mayflies are recognized as one of the most

\footnotetext{
*Corresponding author: Koen.Lock@UGent.be
}

sensitive groups of macroinvertebrates, which are characteristic for waters with a high ecological quality.

In Belgium, nature conservation policy is the responsibility of the regional governments (Flanders, Brussels and Wallonia), and a regional scale is therefore appropriate to perform faunistic studies or when developing red lists. Flanders, which is the Dutch-speaking part of Belgium, has a population of 6.2 million inhabitants and a high population density of 456 citizens. $\mathrm{km}^{-2}$. About $88 \%$ are connected to a sewage system; however, only $70.3 \%$ are actually treated (VMM, 2009). Flanders is also heavily industrialized, and the agriculture causes a heavy pressure as $53 \%$ of the land is used for (mainly intensive) agriculture (VMM, 2009). In addition, thousands of weirs have been built for flood control, hundreds of kilometres of artificial banks have been installed and the majority of the river channels have been straightened. To obtain a good water quality in all water bodies, which should be the case by 2015 according to the WFD (European Council, 2000), there is still a lot of work to be done. At the moment, most attention is focused on watercourses with the poorest water quality; however, ameliorating water quality from bad to poor or moderate will not help populations of sensitive organisms. A first step should thus be to protect the sites that still have a high water quality. 

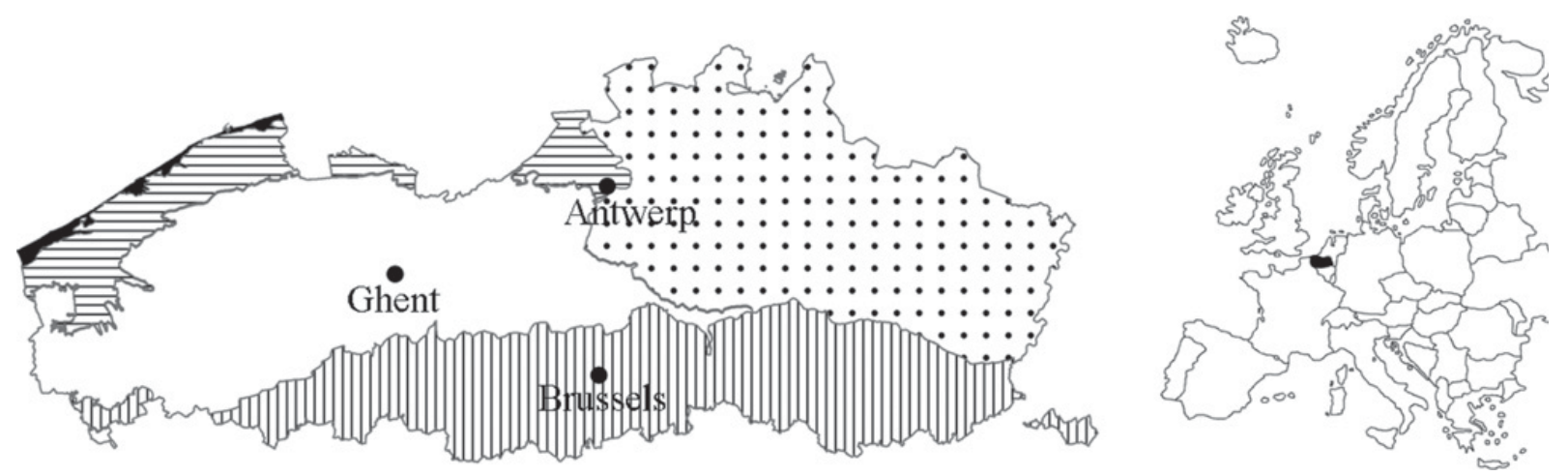

Fig. 1. Map of Flanders with indication of the different ecoregions: dune area (black), polder area (horizontal stripes), sandy region (white), Campine region (dots) and loamy region (vertical stripes); the location of Flanders has been marked on the map of Europe.

In addition, most suitable habitats are now isolated and therefore populations are extremely vulnerable to extinction, while recolonization is hardly possible. Therefore, also intentional interventions are needed that are directed to the connection of isolated populations by solving the present bottlenecks that prevent the necessary expansion of the remaining populations. To efficiently allocate restoration efforts, ecological models could be useful for the assessment of these bottlenecks in the river basin (Mouton et al., 2008).

Despite their importance as water quality indicators, mayflies have hardly received any attention in Flanders. Knowledge about the distribution of sensitive aquatic invertebrates such as mayflies could help to define priorities in water management, and locations containing rare species or a high species richness deserve priority in nature conservation. In the present study, a checklist of the mayflies occurring in Flanders is presented, distribution maps for all species are plotted, and the relationship between the occurrence of the different species and the water characteristics is analysed.

\section{Materials and methods}

All available Ephemeroptera from Flanders and Brussels (a map indicating the ecoregions is presented in Fig. 1) were identified to species level using the identification keys by Bauernfeind and Humpesch (2001) and Eiseler (2005). Most collection material was present in the Royal Belgian Institute for Natural Sciences, where also the samples of the Flemish Environment Agency are conserved. In the context of water quality monitoring by the Flemish Environment Agency, macroinvertebrates have been sampled at several thousand sampling points since 1989. However, it should be noted that especially running waters are monitored, while stagnant waters are underrepresented. During monitoring, macroinvertebrates are sampled using a standard handnet, as described by Gabriels et al. (2010). With the handnet, a stretch of $10-20 \mathrm{~m}$ is sampled during approximately $5 \mathrm{~min}$. Sampling effort is proportionally distributed over all accessible aquatic habitats. This includes the bed substrate (stones, sand or mud), macrophytes (floating, submerging and emerging), immersed roots of overhanging trees and all other natural or artificial substrates, floating or submerged in the water. Each aquatic habitat is explored, in order to collect the highest possible diversity of macroinvertebrates. For this purpose, kicksampling is performed. In addition to the handnet sampling, animals are manually picked from stones, leaves or branches. Conductivity, $\mathrm{pH}$, oxygen content and water temperature are measured at each sampling point. The highest point in the study area has an altitude of only $288 \mathrm{~m}$ and the whole region can thus be considered as lowland.

To analyse the distribution and ecology of mayflies, literature data as well as all available data from the collections and the water quality monitoring data from the Flemish Environment Agency were brought together in one dataset. In addition, about 30 field trips were carried out during the last two years to collect missing data. However, only the monitoring data of the Flemish Environmental Agency could be linked to environmental variables. A direct gradient analysis was applied to determine which environmental parameters might be responsible for the differences in species composition, since environmental variables were explicitly incorporated in the analysis. To test whether a linear or unimodal method was needed, a Detrended Correspondence Analysis (DCA) was performed. Since the Length of Gradient (LoG) was greater than four, a unimodal method was needed, and therefore, the Canonical Correspondence Analysis (CCA) option from the program package CANOCO (Ter Braak, 1988) was applied. A log-transformation $(\log (x+1))$ was applied prior to the CCA to normalize the data.

\section{Results}

For the present study, more than 130000 mayflies were identified, mainly larvae. They represented 5985 records, of which only 343 dated from before 1990. Of the 32 species that were recorded for Flanders and Brussels (Table 1), four were not previously reported, Caenis lactea, Ephemera glaucops, Electrogena ujhelyii (previously reported as Electrogena lateralis) and Rhithrogena picteti 
Table 1. Checklist of the Ephemeroptera in Flanders.

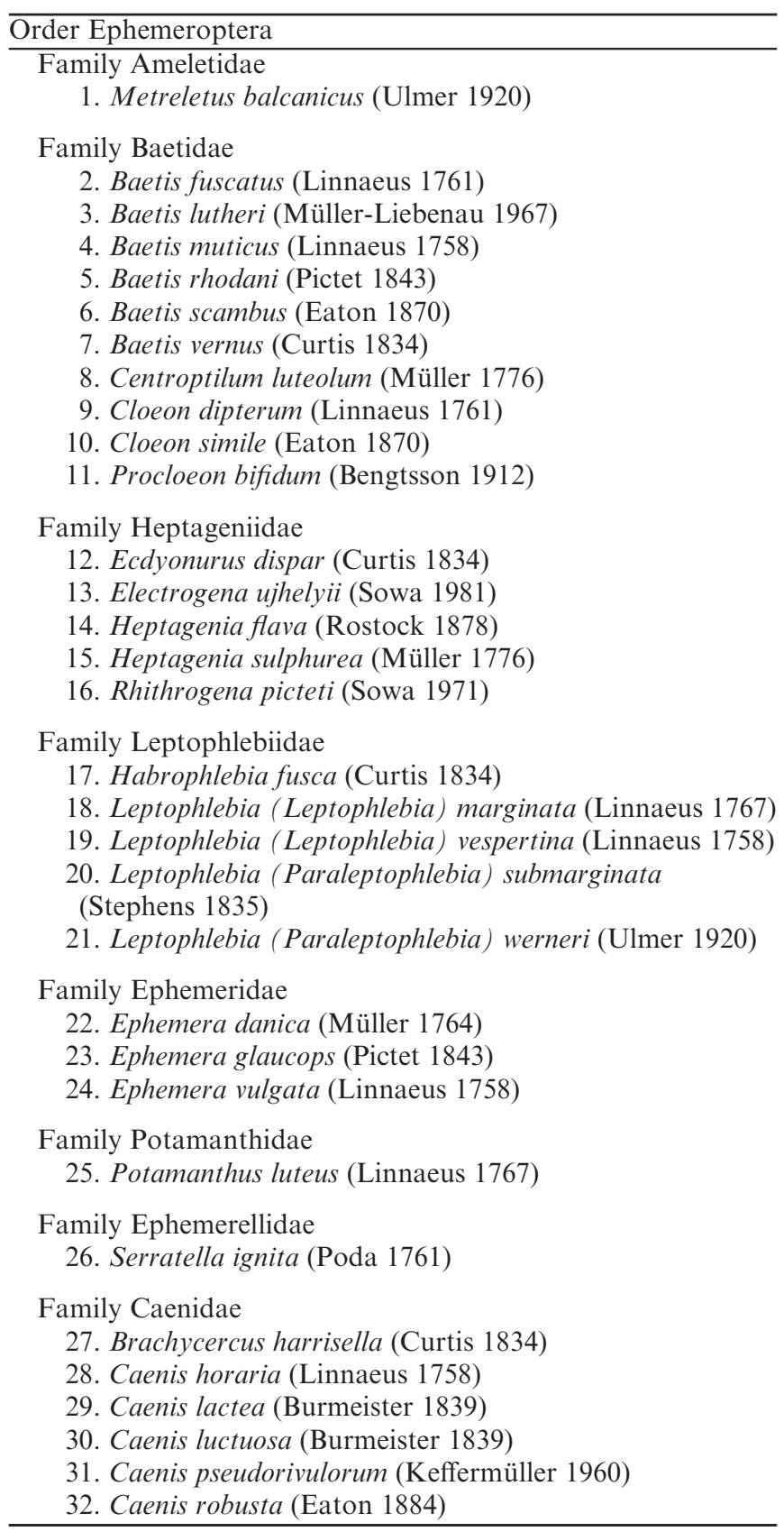

(previously reported as Rhithrogena savoiensis or Rhithrogena semicolorata), and all these species are also new for the Belgian fauna. Six species were not observed since 1990: Metreletus balcanicus, Baetis lutheri, Ecdyonurus dispar, Heptagenia sulphurea, R. picteti and Potamanthus luteus (Fig. 2). Most of the 26 remaining species have a restricted distribution (Fig. 2).

Most mayflies were mainly found in waters with a high oxygen content, but some, especially Cloeon dipterum and Caenis robusta, also tolerated relatively low oxygen levels (Fig. 3). The latter two species also tolerated relatively high conductivities (Fig. 3). Several species, such as Baetis fuscatus and Procloeon bifidum, were mainly found in the
Campine region, where watercourses contained acid or circumneutral water (Fig. 3). Other species, such as Baetis rhodani and E. ujhelyii, mainly occurred in the loamy region, where watercourses contained alkalic water.

In a CCA, the first and the second axis had an eigenvalue of 0.22 and 0.12 , respectively. Conductivity and oxygen content explained most of the variance in the species composition of the mayflies along the first axis, while $\mathrm{pH}$ explained most of the variance along the second axis (Fig. 4). The relatively tolerant species $C$. dipterum and $C$. robusta were characteristic for waters with a low oxygen content and a high conductivity, while most species preferred higher oxygen concentrations and a lower conductivity. Along the second axis, the species could be separated into species preferring a low $\mathrm{pH}$ such as $P$. bifidum and Heptagenia flava, which were characteristic for the Campine region, and species preferring alkalic waters such as B. rhodani and E. ujhelyii, which were characteristic for the loamy region, but also species typical for stagnant waters such as Caenis horaria.

\section{Discussion}

In the present study, the eutrophication gradient, represented by conductivity and dissolved oxygen concentration, was the most important factor determining mayfly community composition. Also in other studies about Ephemeroptera, eutrophication has often been reported as the main factor affecting species assemblages (i.e. Hrovat et al., 2009). Apart from eutrophication, $\mathrm{pH}$ also influenced community composition, with the Campine region, which is characterized by a relatively low $\mathrm{pH}$, containing different species compared to the loamy region and stagnant waters, which have a higher $\mathrm{pH}$. This is in accordance with the fact that mayflies are generally reported as one of the most acid-sensitive macroinvertebrate taxa (Lepori et al., 2003; Tixier et al., 2009). B. rhodani has even been used as an indicator for acidification due to its sensitivity to acidity (Raddum and Fjellheim, 1984; Tixier et al., 2009).

Neither Flanders nor Belgium contains any endemic species and most species recorded in Flanders have a West Palaearctic or even a Transpalaearctic distribution, which is usually the case for lowland species (Beketov, 2009). Using the categories proposed by the IUCN Species Survival Commission (IUCN Species Survival Commission, 1994) and adapted for Flanders (Maes and Van Swaay, 1997; Maes et al., 2003), mayflies were divided into categories according to their rarity. Of the 32 species that have been reported (Table 1), six species are extinct in Flanders: $R$. picteti was last observed in 1964, M. balcanicus in 1953, B. lutheri in 1946, H. sulphurea in 1918 and two species were not recorded since they were recorded by De Selys-Longchamps (1888): E. dispar and P. luteus. With the exception of $M$. balcanicus, all species that are extinct in Flanders still occur in Wallonia (southern part of Belgium). Amelioration of the ecological water quality could therefore induce the recolonization of 


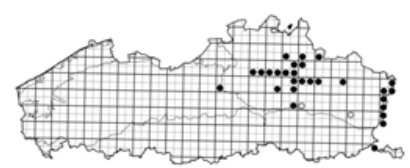

Baetis fuscatus

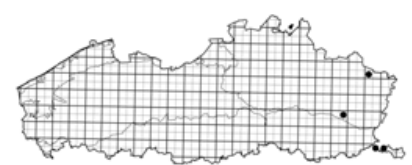

Baetis scambus

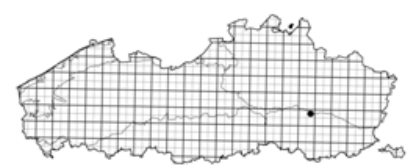

Caenis lactea

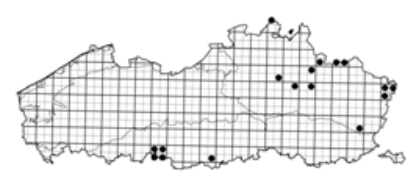

Centroptilum luteolum

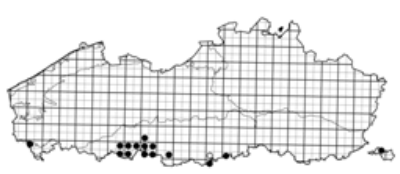

Electrogena ujhelyii

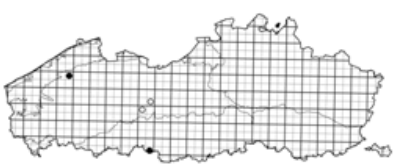

Habrophlebia fusca

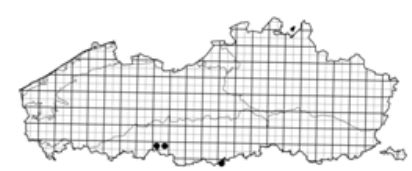

Leptophlebia submarginata

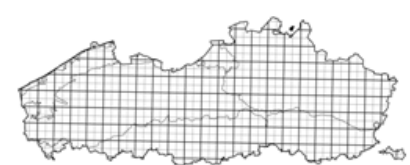

Potamanthus luteus

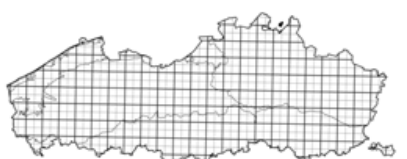

Baetis lutheri

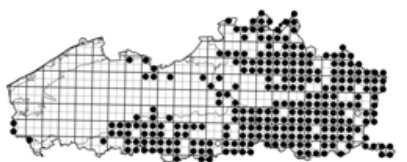

Baetis vernus

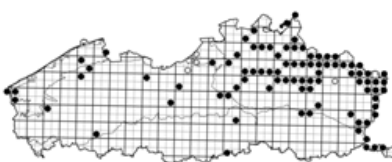

Caenis luctuosa

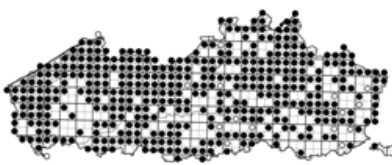

Cloeon dipterum

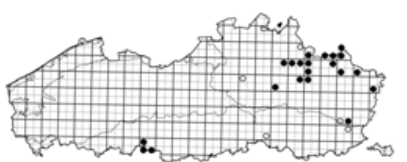

Ephemera danica

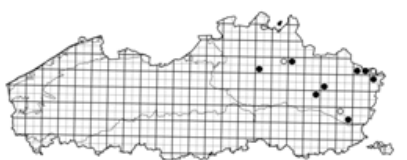

Heptagenia flava

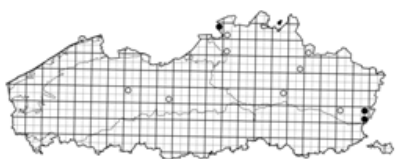

Leptophlebia vespertina

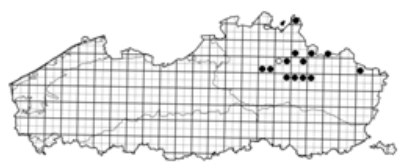

Procloeon bifidum

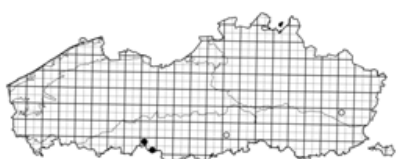

Baetis muticus

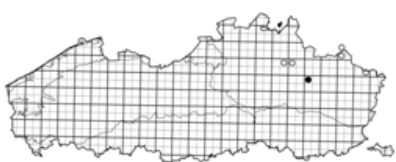

Brachycercus harrisella

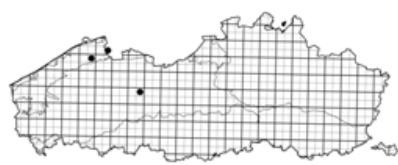

Caenis pseudorivulorum

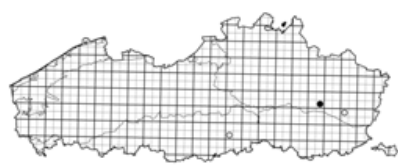

Cloeon simile

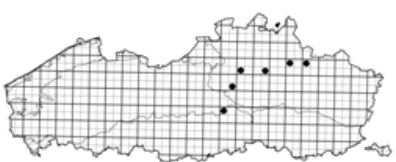

Ephemera glaucops

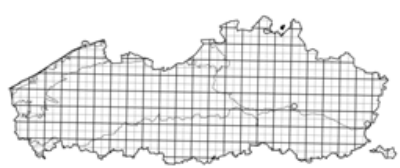

Heptagenia sulphurea

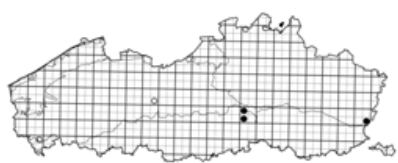

Leptophlebia werneri

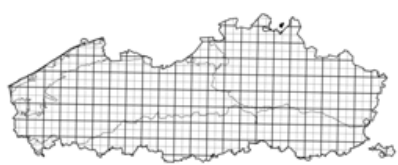

Rhithrogena picteti

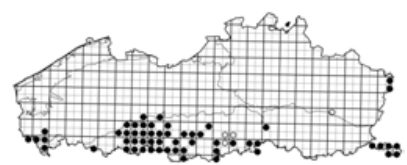

Baetis rhodani

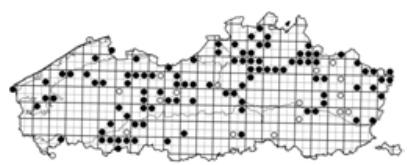

Caenis horaria

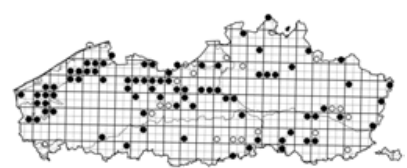

Caenis robusta

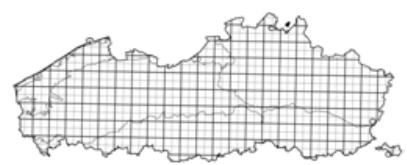

Ecdyonurus dispar

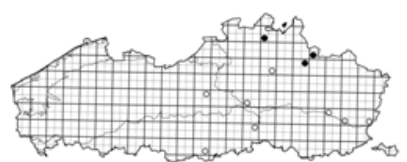

Ephemera vulgata

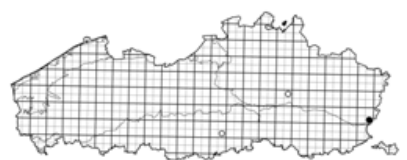

Leptophlebia marginata

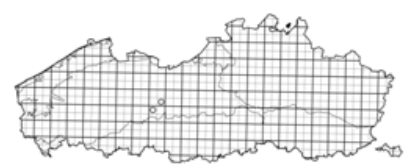

Metreletus balcanicus

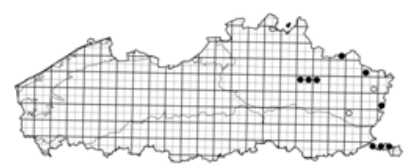

Seratella ignita

Fig. 2. Distribution of the mayflies in Flanders before $1990(\bigcirc)$ and since $1990(\bullet)$, with indication of the ecoregions and a grid of $5 \times 5 \mathrm{~km}$ UTM squares.

Flanders by these species without much difficulty. Due to the lack of historical records, however, several species were probably already extinct before they were ever recorded.
Fifteen of the remaining species are very rare and occur in less than $2 \%$ of the $5 \times 5 \mathrm{~km}$ UTM squares, five species are rare and occur in less than $5 \%$ of the squares, and three species are fairly rare as they occur in less than $15 \%$ of 


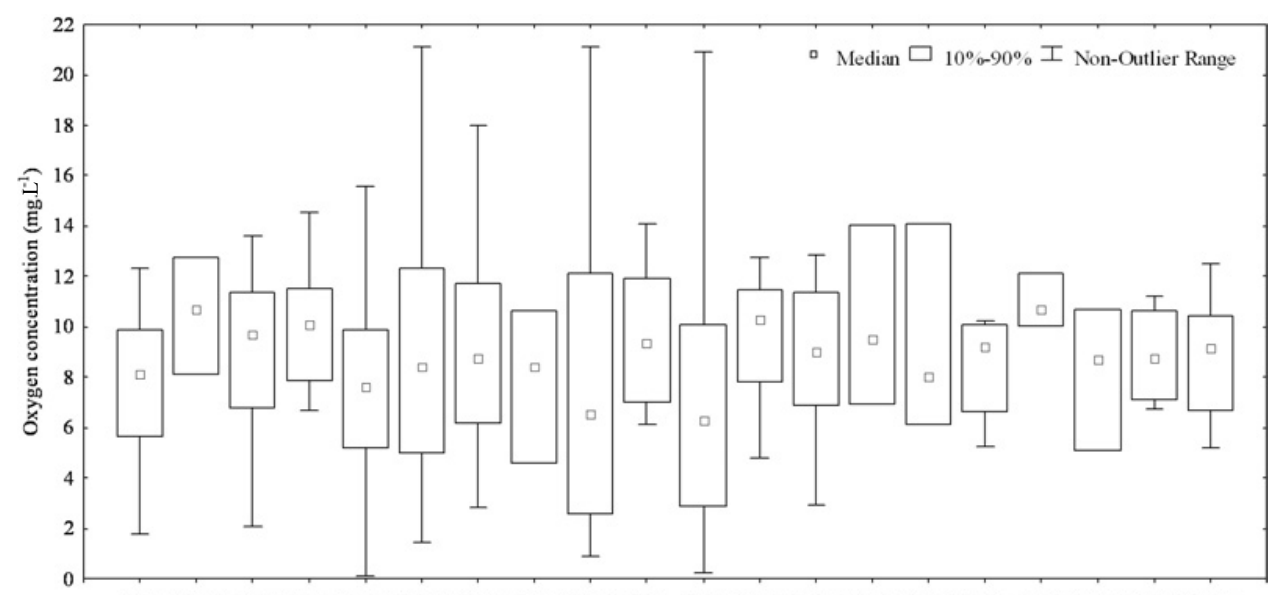

B.fus B.mut B.rho B.sca B.ver C.hor C.luc C.pse C.rob C.lut C.dip E.ujh E.dan E.gla E.vul H.fla L.sub L.wer P.bif S.ign

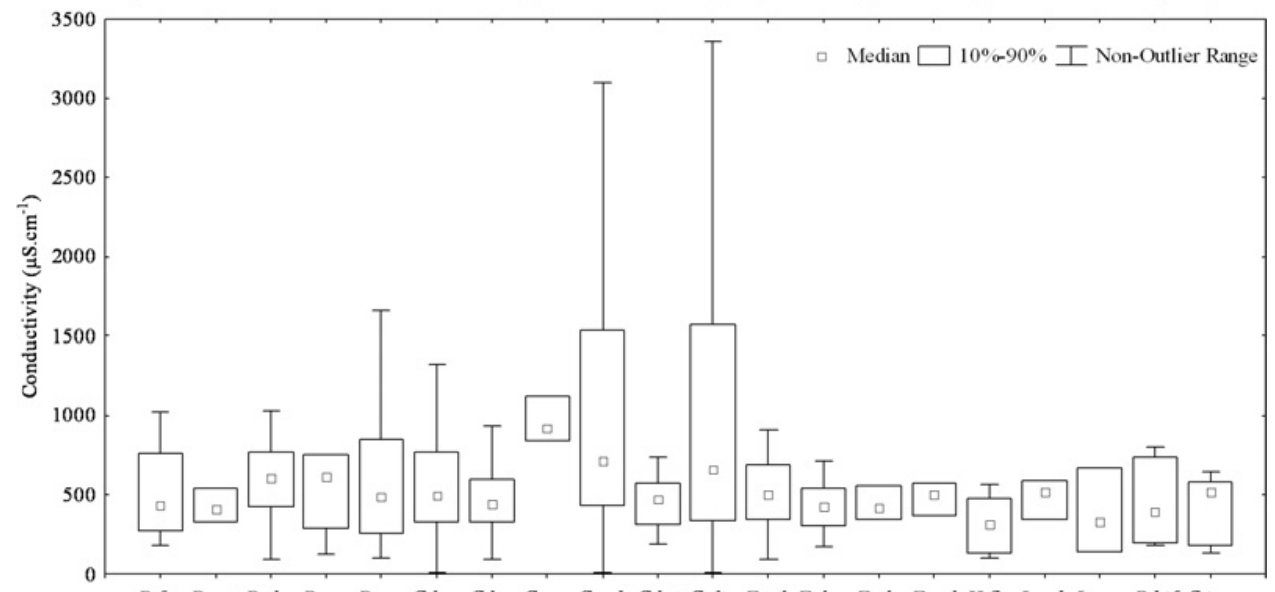

B.fus B.mut B.rho B.sca B.ver C.hor C.luc C.pse C.rob C.lut C.dip E.ujh E.dan E.gla Evvul H.fla L.sub L.wer P.bif S.ign

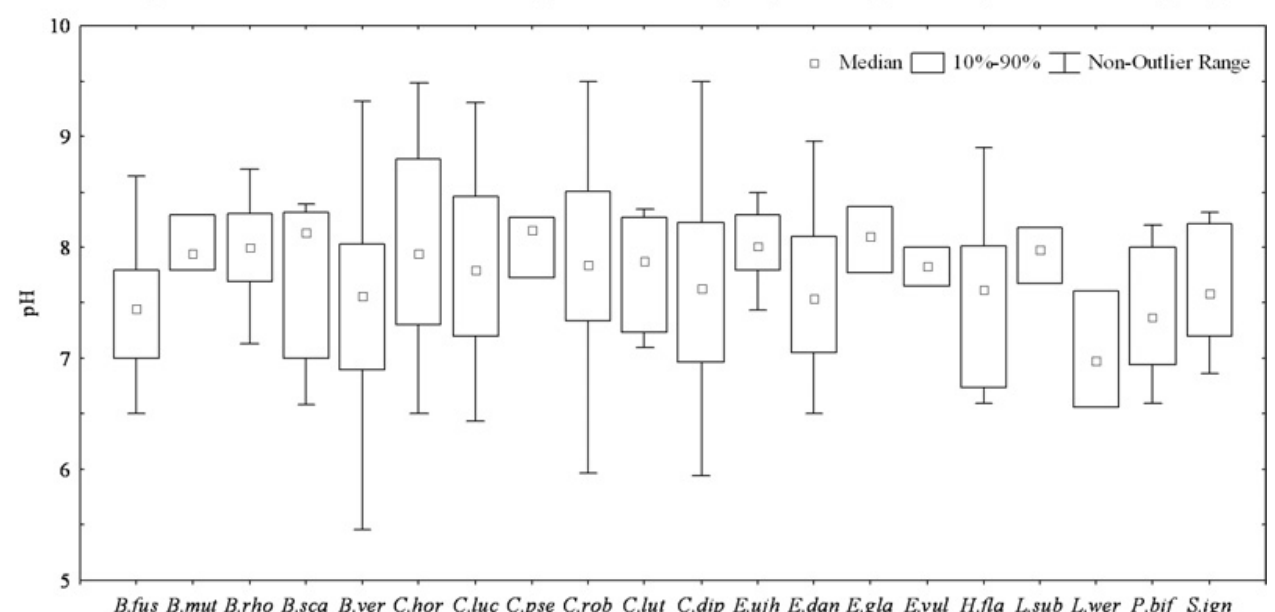

Fig. 3. Box and whisker plots of oxygen concentration, conductivity and $\mathrm{pH}$ in the watercourses containing Baetis fuscatus (B.fus; $n=108)$, Baetis muticus (B.mut; $n=4)$, Baetis rhodani (B.rho; $n=283)$, Baetis scambus $($ B.sca; $n=14)$, Baetis vernus $($ B.ver; $n=1881)$, Caenis horaria (C.hor; $n=268)$, Caenis luctuosa (C.luc; $n=311)$, Caenis pseudorivulorum $($ C.pse; $n=7)$, Caenis robusta $($ C.rob; $n=158)$; Centroptilum luteolum (C.lut; $n=31)$, Cloeon dipterum (C.dip; $n=1857)$, Electrogena ujheyii (E.ujh; $n=99)$, Ephemera danica (E.dan; $n=89)$, Ephemera glaucops (E.gla; $n=7)$, Ephemera vulgata (E.vul; $n=6)$, Heptagenia flava $($ H. fla; $n=13)$, Leptophlebia submarginata $($ L.sub; $n=5)$, Leptophlebia werneri (L.wer; $n=8)$, Procloeon bifidum (P.bif; $n=26)$ and Serratella ignita $(S . i g n ; n=26)$.

the squares (Fig. 2). Only three species are not rare in Flanders: $C$. horaria, Baetis vernus and $C$. dipterum. $B$. vernus is known to be a relatively tolerant species
(Beketov, 2004; Tixier et al., 2009), while C. horaria is known from eutrophic conditions and $C$. dipterum has even been found in hypertrophic conditions (Menetrey 


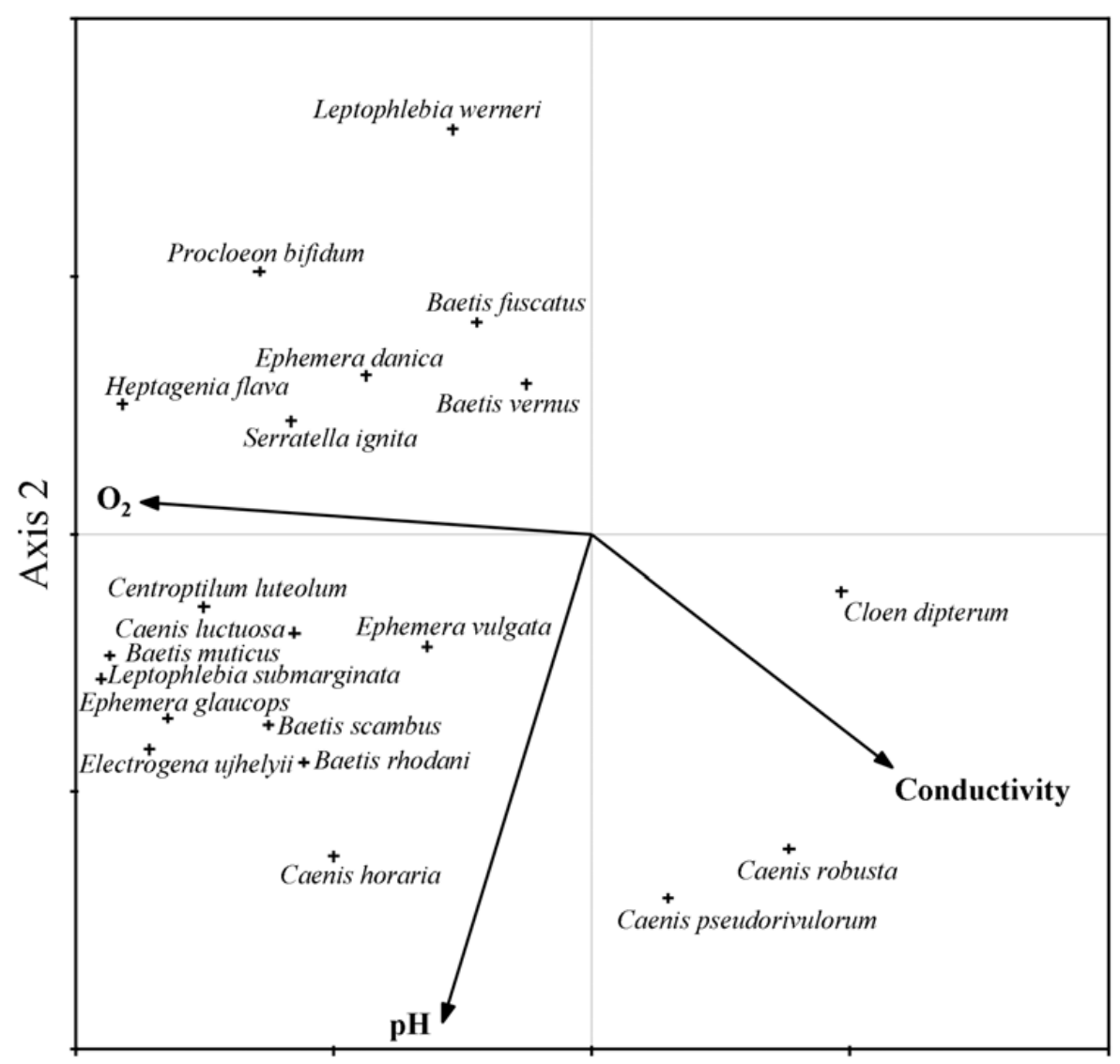

Axis 1

Fig. 4. Biplot of the species scores and the environmental variables $\mathrm{pH}$, conductivity and oxygen concentration.

et al., 2008), and the latter is the European species that exhibits the greatest saprobic index among mayflies (Tachet et al., 2000). Insufficient historical data are available to calculate trends and, therefore, no red list is presented. However, it is obvious that a number of the remaining mayfly species in Flanders are endangered. Most remaining mayfly populations are especially vulnerable since they are restricted to springs located in isolated forest remnants. Species that are restricted to large streams, such as E. dispar, H. sulphurea and P. luteus, still do not stand a chance in Flanders. Among river macroinvertebrates, only stoneflies seem to be worse off, with barely one species present in more than $10 \%$ of the squares (Lock and Goethals, 2008).

Because the network of the Flemish Environment Agency is very elaborate, it can be assumed that the maps give a good idea of the present distribution of the mayfly species occurring in running waters. However, much less information is available about the species living in stagnant waters because these types of waters are not monitored routinely by the Flemish Environment Agency. Species such as C. lactea, Caenis pseudorivulorum, Cloeon simile and Leptophlebia vespertina might therefore be more common than indicated by the distribution maps (Fig. 2).

\section{Conclusion}

Of the 32 mayfly species that have been recorded in Flanders, already six became extinct, while most of the remaining species are rare. Only a few species that are able to tolerate relatively low oxygen levels and high conductivities are still common. It can only be hoped that the WFD will encourage Flanders to undertake the necessary steps to achieve an ecological water quality that is sufficient to support sustainable populations of sensitive aquatic invertebrates such as most mayfly species.

Acknowledgements. We thank the Royal Belgian Institute of Natural Sciences and the Flemish Environment Agency for the opportunity to study their collections. For the help during the study of the collections, we thank Rose Sablon, Thierry Backeljou, Jérôme Constant and Patrick Grootaert (Royal Belgian Institute of Natural Sciences), and Erik Ghyselbrecht, Joost Mertens, Thierry Warmoes, Christophe Maes, Saskia Scheers, Frank Lavens, Dirk Roos and Wim Gabriels (Flemish Environmental Agency). Finally, we thank Tim Adriaens from the Research Institute for Nature and Forest for plotting the distribution maps. Koen Lock is currently supported by a postdoctoral fellowship from the Fund for Scientific Research (FWO-Vlaanderen, Belgium). 


\section{References}

Bauernfeind E. and Humpesch U.H., 2001. Die Eintagsfliegen Zentraleuropas (Insecta: Ephemeroptera): Bestimmung und Ökologie, Verlag des Naturhistorischen Museums, Wien, $239 \mathrm{p}$.

Beketov M.A., 2004. Different sensitivity of mayflies (Insecta, Ephemeroptera) to ammonia, nitrite and nitrate: linkage between experimental and observational data. Hydrobiologia, 528, 209-216.

Beketov M.A., 2009. Cross-Eurasian and altitudinal distribution of lotic mayflies - species with wider altitudinal ranges have narrower geographical distribution. Ann. Limnol. - Int. J. Lim., 45, 209-218.

De Pauw N. and Vanhooren G., 1983. Method for biological quality assessment of watercourses in Belgium. Hydrobiologia, 100, 153-168.

De Selys-Longchamps E., 1888. Catalogue raisonné des Orthoptères et des Nevroptères de Belgique. Ann. Soc. Entomol. Belg., 32, 103-203.

Eiseler B., 2005. Bildbestimmungsschlüssel für die Eintagsfliegenlarven der deutschen Mittelgebirge und des Tieflandes. Lauterbornia, 53, 1-112.

European Council, 2000. Directive 2000/60/EC of the European Parliament and of the Council of 23 October 2000 establishing a framework for Community action in the field of water policy, Official Journal of the European Communities L327, 22 December 2000, Brussels, 72 p.

Gabriels W., Lock K., De Pauw N. and Goethals P.L.M., 2010. Multimetric macroinvertebrate index Flanders (MMIF) for biological assessment of rivers and lakes in Flanders (Belgium). Limnologica, 40, 199-207.

Hrovat M., Urbani G. and Sivec I., 2009. Community structure and distribution of Ephemeroptera and Plecoptera larvae in lowland karst rivers in Slovenia. Aquat. Insects, 31, 343-357.

IBN, 1984. Biological quality of watercourses. Determination of the biotic index based on aquatic macroinvertebrates, NBN T92-402 (in Dutch and French), Belgian Institute of Normalization, Brussels, 11 p.

IUCN Species Survival Commission, 1994. IUCN Red List categories, IUCN, Gland, 21 p.

Lepori F., Barbieri A. and Ormerod S.J., 2003. Effects of episodic acidification on macroinvertebrate assemblages in Swiss Alpine streams. Freshwater Biol., 48, 1873-1885.
Lock K. and Goethals P.L.M., 2008. Distribution and ecology of the stoneflies (Plecoptera) of Flanders (Belgium). Ann. Limnol. - Int. J. Lim., 44, 203-213.

Maes D. and Van Swaay C.A.M., 1997. A new methodology for compiling national Red Lists applied to butterflies (Lepidoptera, Rhopalocera) in Flanders (N-Belgium) and the Netherlands. J. Insect Conserv., 1, 113-124.

Maes D., De Bruyn L. and Kuijken E., 2003. Red List criteria in Flanders. In: de Iongh H.H., Bánki O.S., Bergmans W. and van der Werff M.J. (eds.), Harmonization of Red lists in Europe, Proceedings International Seminar, 27-28 November 2002, The Netherlands Foundation for International Nature Protection, Mededelingen No. 38, Leiden, 217-223.

Menetrey N., Oertli B., Sartori M., Wagner A. and Lachavanne J.B., 2008. Eutrophication: are mayflies (Ephemeroptera) good bioindicators for ponds? Hydrobiologia, 597, 125-135.

Mouton A.M., Van der Most H., Jeuken A., Goethals P.L.M. and De Pauw N., 2008. Evaluation of river basin restoration options by the application of the water framework directive explorer in the Zwalm River basin (Flanders, Belgium). River Res. Appl., 23, 1-16.

Raddum G.G. and Fjellheim A., 1984. Acidification and early warning organisms in freshwater in western Norway. Verh. Int. Ver. Limnol., 22, 1973-1980.

Tachet H., Richoux P., Bournaud M. and Usseglio-Polatera P., 2000. Invertébrés d'eaux douces, Systématique, biologie, écologie, CNRS Éditions, Paris, 588 p.

Ter Braak C.J.F., 1988. CANOCO - a FORTRAN program for canonical community ordination by (partial) (canonical) correspondence analysis, principal components analysis and redundancy analysis (version 2.1), Agricultural Mat. Group, Ministry of Agriculture and Fisheries (Netherlands), Wageningen, $95 \mathrm{p}$.

Tixier G., Felten V. and Guérold F., 2009. Life cycle strategies of Baetis species (Ephemeroptera, Baetidae) in acidified streams and implications for recovery. Fund. Appl. Limnol., 174, 227-243.

VMM, 2009. MIR-T 2008 Indicator report [in Dutch], Van Steertegem M. (red.), Environmental Report Flanders, Flemish Environment Agency, Aalst, 164 p.

VMM, 2010. Annual report water 2009 [in Dutch], Flemish Environment Agency. Available online at: http://www.vmm. be/pub/jaarrapport-water-2009. 